\title{
Harmonizing the Joint Regulation of The Minister Of Religion And The Minister Of Home Affairs Number 9 And Number 8 Of 2006 Chapter Iv Concerning The Establishment Of House Of Worship Toward The Difficulties Of Establishing Religious House In Medan City
}

\author{
Budi Sulistiyo $^{1}$, Elvira Fitriyani Pakpahan ${ }^{2}$, Ramon Novrial $^{3}$ \\ \{tiosaputra@gmail.com\} \\ Universitas Prima Indonesia ${ }^{123}$
}

\begin{abstract}
The synagogue is the most essential requirement which is indispensable for implementing an attitude of religiosity together. The need for the construction of houses of worship is sometimes constrained because it cannot fulfill the regulatory requirements in the Joint Regulation of the Minister of Religion and the Minister of Home Affairs Number 9 and Number 8 of 2006 CHAPTER IV concerning the construction of houses of worship. This study uses qualitative research methods using several texts and data relating to the construction of houses of worship. Exposure of regulations through primary data in the form of regulations on the establishment of places of worship, the 1945 Constitution, the Human Rights Law, and secondary supporting data. Then combined with interview data with several Buddhist stakeholders and figures in Medan City. The analysis in research describes a legal fact that happens to be helpful. The existence of this regulation is a condition with expectations to be harmonized so that the regulation can provide a value of justice for Buddhists in Medan City who want to build a house of worship but in a small quantity community.
\end{abstract}

Keywords: Houses of Worship, Licensing, Legal Effectiveness

\section{Introduction}

The Unitary State of the Republic of Indonesia regulates the construction of houses of worship through Joint Regulations of the Minister of Religion and the Minister of Home Affairs Number 9 and Number 8 of 2006 known as PBM. The Joint Ministerial Regulation contains the definition of houses of worship and the requirements that must be met for the construction of houses of worship. The house of worship itself has a definition as a building that has special characteristics that are used for permanent worship for adherents of each religion but does not include family places of worship, according to Article 1 paragraph 2 of the regulation.

The requirements for the construction of houses of worship are the fulfilment of administrative and technical requirements for buildings, which further fulfilment of the permits of residents as contained in Article 14 paragraph 2 states, in the construction of houses of worship, it is necessary to obtain community support from the local environment at least 60 people authorized by the village head or head. village. Then, the construction of houses of 
worship must also complete with a list of names and Identity Cards of users of houses of worship of at least 90 people. The approval document is then legalized by local officials following the level of the boundaries of the area. After that, all files need to receive a written recommendation from the Head of the District or City Head of the Ministry of Religion and Religious Harmony Forum (FKUB). If all permit documents are completed, the committee for building houses of worship can apply for a building permit to the regional head to obtain an IMB[1].

The difficulty of building a House of Worship, especially for minority groups, is the case with Medan Buddhists [2]. The Buddhists in Medan are indeed a minority group. Based on data in numbers, in 2015, the number of Buddhists in Medan was 303,000 inhabitants. In general, efforts to establish Houses of Worship usually occur due to the minimal number of followers of certain religions in an area. Concerning the establishment of places of worship as stipulated in the Joint Regulation of the Minister of Religion and the Minister of Home Affairs Number 9 and Number 8 of 2006, this PBM also complicates the realization of the establishment of places of worship for people with minimal religious adherents in an area.

The heterogeneous Indonesian society is very risky for religious conflict, so the government's effort is to make law enforcement efforts in licensing the construction of houses of worship to maintain a cool climate of order and security in Indonesian society. The Joint Decree of the Minister of Religion and the Minister of Home Affairs Number 9 and Number 8 of 2006 Chapter IV Concerning the Establishment of Houses of Worship and referred to as the Joint Ministerial Regulation (PBM) is the government's action in trying to realize religious harmony by forming the Forum for Religious Harmony (FKUB). Through the Joint Ministerial Regulation on the establishment of Houses of Worship in 2006, the government is trying to make regulations for the establishment of Houses of Worship to maintain public order.

There are also many problems with the permit for houses of worship in various regions in Indonesia, one of which is also in the city of Medan which is one of the miniatures of the Indonesian state, because Medan is known to have a wealth of diverse community treasures. Likewise, the religion followed by the people of Medan, which consists of Islam, Christianity, Hinduism, Buddhism, and Konghuchu. Moslems and Christians are a fact in the field that most people build houses of worship in Medan. Houses of worship were established in various places, even Christian communities who live in Medan have houses of worship in shopping centres in Medan, such as the Medan Plaza and Palladium Plaza. There are dynamics of problems in the construction of houses of worship in the city of Medan which also occur in several places such as houses of worship which were torn down, governance of building construction of houses of worship whose permits for construction are unclear.

The problem of constructing a house of worship is also experienced by Buddhists. This was conveyed by several Buddhist leaders/leaders in the city of Medan that the average number of Buddhists who are small in number in an area in the city of Medan finds it difficult to realize having a house of worship. This is because administratively and technically the Buddhists in the area will not be able to meet these requirements given the limited number of Buddhists. Thus, in this way, Buddhists often cancel their intention to build a house of worship, which is very necessary to carry out religious activities together in a community.

Based on the description above, it is interesting to present a study entitled Harmonization of Joint Regulations of the Minister of Religion and the Minister of Home Affairs Number 9 of 2006 and Number 8 of 2006 Chapter IV Concerning the Construction of Houses of Worship Against the Difficulties of Establishing Buddhist Houses of Worship in Medan City. 


\section{Research Methods}

Qualitative research methods are the methods used in this study. This qualitative method is used because research problems need to be explored to get a deep understanding [3]. The author describes how to synchronize the regulations for the establishment of places of worship that are contained in the joint ministerial decree. The author uses a literature study with a qualitative research method, namely describing the results of research with literature [4].

Sources of data in this study come from literature data that has been collected, namely in the form of books, seminar papers, writings of scientists who are competent on this issue or other documentation [5]. Qualitative data collection is done using natural conditions techniques, primary data sources, and observation techniques, in-depth interviews, and documentation. Data analysis is processed by compiling data that has been collected through interviews, field notes, and other materials systematically so that these findings can become information material related to the synchronization of regulations on the establishment of places of worship.

\section{Results and Discussion}

3.1. Legal Arrangements for Joint Regulations of the Minister of Religion and the Minister of Home Affairs No.9 of 2006 and No.8 of 2006 Chapter IV concerning the Establishment of Houses of Worship with the Laws and Regulations Governing Human Freedom in Carrying Out Worship

\section{Rule of Law Aspects in the Right to Build Houses of Worship}

The Unitary State of the Republic of Indonesia strives to create a conducive climate so that individuals can properly perform worship according to their respective religions and beliefs [6]. The importance of a house of worship to carry out worship together was what made the Indonesian government initially not oblige the processing of permits for the establishment of places of worship, especially since initially, areas in Indonesia were generally homogeneous. As time goes by, as well as increasing population movements, regions in Indonesia become more heterogeneous, and problems arise related to the construction of places of worship.

In dealing with conflicts regarding the establishment of places of worship, the Indonesian government issued a regulation on the construction of places of worship. This regulation on the establishment of places of worship was first issued in 1969 in the form of a Joint Decree (SKB) of the Minister of Religion and the Minister of Home Affairs Number 01 / BER / MDN / 1969 concerning the Implementation of Duties of Government Officials in Ensuring Order and Smooth Implementation of Development and Worship by Its adherents [7].

Not all of the issuance of the PBM had a positive impact as expected, instead it became an instrument to close down churches in various places. On this basis, the government then revised the PBM-to-PBM No. 9/2006 and 8/2006 and therein also regulates the establishment of places of worship. PBM does have differences with SKB, but both have similarities, namely requiring the processing of a permit for places of worship.

Based on the aforementioned points, a correlation can be drawn that the relationship between Public Policy, Religious Freedom and the construction of houses of worship are closely related. Public policy as a legal arrangement established by the government as a regulation that must be implemented. Then, freedom of religion is the right of every Indonesian citizen to be able to embrace their respective religions and beliefs that are guaranteed by the 1945 
Constitution and Article 4 jo. Article 22 of Law Number 39 Year 1999 regarding Human Rights. So that the connection is that the establishment of houses of worship as a real need for religious communities in carrying out religious activities must be realized based on public policies that have been established by the government in the form of Joint Ministerial Regulations number 9 and 8 of 2006 Chapter IV Article 14 concerning the establishment of houses of worship.

Houses of Worship in Indonesia are buildings that have certain characteristics specifically used for permanent worship by adherents of each religion; does not include a family place of worship [8]. This has been regulated in the Joint Regulation of the Minister of Religion and the Minister of Home Affairs No. 9 and Number 8 of 2006 concerning Guidelines for Implementing the Duties of Regional Heads / Deputy Regional Heads in Maintaining Religious Harmony, Empowering Religious Harmony Forums, and Establishing Houses of Worship ("Joint Ministerial Regulation of 2 Ministers"). It was also stated that the construction of a house of worship must meet the administrative and technical requirements of the building.

Furthermore, in Chapter IV Article 14, the construction of a house of worship must meet special requirements, including:

a) List of names and KTPs of users of places of worship of at least 90 people which are legalized by local officials;

b) Support from the local community at least 60 (sixty) people who are endorsed by the lurah / village head;

c) A written recommendation from the head of the district / city religious affairs department head; and

d) Written recommendation from regency / municipality Forum for Religious Harmony.

e) Application for establishment is submitted by the development committee to the regent / mayor to obtain an IMB. The construction committee is formed by religious communities, religious organizations and / or administrators of related places of worship. Furthermore, the head of the local regional government will make a decision no later than 90 days after the application is submitted by the Development committee [9].

Understanding the implementation of the law in Chapter IV Article 14 of the establishment of houses of worship in a region, there are differences in the fulfilment of the requirements for the establishment of houses of worship, especially in communities with religious minorities. The difficulty in fulfilling the requirements for the construction of places of worship is a major problem for religious minorities. Therefore, there are several matters related to the requirements for the establishment of houses of worship which should be reviewed again based on regional conditions related to the population of religions in an area.

Practicing worship in accordance with one's religion is basically a human right that cannot be reduced under any circumstances and by anyone. Such is the guarantee provided in Article 4 jo. Article 22 of Law no. 39 of 1999 concerning Human Rights jo. Article 29 of the 1945 Constitution. The intention of the above regulations is aimed at maintaining harmony between religious communities. As is well known, the Unitary State of the Republic of Indonesia recognizes various religions including Islam and Christianity

\section{Human Rights Aspects in the Right to Build Houses of Worship}

Religious freedom in the context of human rights, particularly political and civil rights, the establishment of places of worship is part of "freedom, either individually or collectively in the public and private sphere to manifest religion and belief." The house of worship is not solely for the purposes of ritual worship, but also for carrying out social activities which are considered in line with the understanding of religion itself [10]. 
Referring to the above matter, the context of the issue of the construction of houses of worship is seen as a human rights issue, because it includes a vehicle for manifesting religion and belief. Referring to these principles, in a human rights perspective the rights to freedom of religion or belief can be summarized into several components, namely: first, internal freedom, everyone has freedom of thought, conscience and religion. This human right includes freedom to adhere to or determine a religion or belief of his own choice, including to change his religion or belief. Secondly external freedom, everyone has freedom, individually or in society, publicly or privately, to manifest his religion or belief in his teaching, experience and worship [11].

Third, there is no compulsion, meaning that no one can become the subject of coercion which will reduce his / her freedom to own or adopt a religion or belief of his choice. Fourth, non-discriminatory, in this case the state has the obligation to respect and guarantee the freedom of religion or belief of all individuals in the territory of the power without distinction of ethnicity, colour, sex, language and belief, politics or opinion, native or immigrant, origin. The five rights of parents and guardians, in this case the state has the obligation to respect the freedom of parents and legal guardians (if any) to ensure that religious and moral education for children is in accordance with its own beliefs. Lastly is Freedom of Institution and Legal Status [12].

Meanwhile, in the theory of law, history, and principles, the issue of human rights or abbreviated as human rights is a fundamental issue of the constitution and the spirit and spirit of constitutional life. The rational basis of human rights in a rule of law that adheres to the principles of constitutionalism and democracy is based on human dignity as a creature of God who must be respected, independent, free, treated equally, cannot be oppressed, tortured and treated unfairly by any form of power or judicial process can reduce its existence as a human [13]. However, in fact it must also be understood that the establishment of places of worship is not in an empty space. He must be part of a social community, which is sometimes not identical with the "adherents", but more broadly, he is in a social and psychological space at the same time because it involves "the livelihood of many people." In this connection it considers appropriate provisions requiring "sociological support" for the establishment of places of worship [13].

The typical picture of Indonesian culture places human rights which do not manifest in absolute human rights but must be combined with human obligations to maintain social harmony and public order. Furthermore, it is inevitable that as the implementation of human rights, the establishment of houses of worship is subject to the provisions of Article $28 \mathrm{~J}$ of the 1945 Constitution which are fully quoted as follows: 1 . Everyone is obliged to respect the human rights of others in an orderly life in society, nation and state. 2. In exercising his rights and freedoms, everyone is obliged to comply with the restrictions established by law for the sole purpose of guaranteeing recognition and respect for the rights and freedoms of others and to fulfil fair demands in accordance with moral considerations religion, security, and public order in a democratic society [14].

Recognition and respect for the rights and freedoms of others and to fulfil fair demands in accordance with moral considerations, religious values, security and public order in a democratic society "in accordance with the provisions of Article 28J of the 1945 Constitution. These are general principles and juridical motives for the need for a permit. the construction of synagogues.

\section{Democratic Aspects in the Right to Build Houses of Worship}

Democracy is often defined as respect for human rights, participation in decision making and equal rights before the law. From here, the idioms of democracy emerge, such as egalite 
(equality), equality (justice), liberty (freedom), human right (human rights), and the like. Religious freedom in the State of Indonesia refers to the 1945 Constitution article 29 paragraph 2 , that every citizen is given the freedom or freedom to embrace his own religion and worship according to that religion and belief. At such a legal level, freedom of religion must be understood as freedom to embrace a religion, whatever the religion [15].

Meanwhile, at the philosophical level, freedom of religion is understood as free to have religion, but at the same time free to have no religion. Such freedom is freedom based on the attitude of humans to determine freely, without interference by any power, including the State, this can happen in a secular state. However, for Indonesia, this does not seem possible, because freedom is interpreted as being free to choose and embrace a certain religion [15].

In determining its freedom to embrace a religion, the State itself does not carry out legal protection, aka discriminatory, especially in terms of protecting religious groups that are often oppressed and marginalized because of their minority. According to experts, the social pluralism perspective counteracts social relations between dominant and hegemonic religious groups and sects, and negates the concentration of social power in one group or stream. Meanwhile, the perspective of cultural pluralism will prevent the loss of one school because it is eliminated by the hegemonic mainstream religious flow, and on the other hand it will ward off the arrogance of the mainstream religious which has often been tempted or historically-empirically committed harassment and oppression of other sects or religions [16].

Meanwhile, political pluralism can be the basis for guaranteeing the freedom to have beliefs and express them without fear of the threat of violence, because there are institutions that manage conflicts of interest between religious denominations. Starting from the aspects of religious pluralism above, according to Billah, religious pluralism has a strong affinity for democratic life in the future, and therefore it can be used as one of the elements of all the elements used to understand and behave towards religious plurality and the existence of schools. religion, as well as being the foundation for the empowerment of a democratic civil society and upholding human dignity [16]. As explained by Haryatmoko, that the teachings of tolerance and religious freedom initiated by Locke negate the existence of coercion both individually and in groups and even through institutions to embrace one religion. In line with Locke, Leibniz's concern about the Catholic-Christian conflict which ended in war for approximately 30 years (1618-1645) encouraged him to think plurally [17].

The government and the DPR have ratified the International Covenant on Civil and Political Rights (Sipol) through Law No. 12/2005. Article 18 paragraph (1) of the Sipol International Covenant protects the right to freedom of thought, conscience and religion, including the right to embrace belief. The right to freedom of religion / belief cannot be reduced, Article 28 E paragraph (1) of the second amendment of the 1945 Constitution recognizes the right of every citizen to freedom of religion or belief, as well as Article 28 I paragraph (1) of the second amendment of the 1945 Constitution, explaining the right to religion and belief is a human right that cannot be reduced, limited under any circumstances. Even Article 28 I paragraph (4) of the 1945 Constitution, the second amendment, emphasizes the obligation of the state, especially the government to protect, promote, enforce and fulfill human rights. The state's obligations include to protect, promote, enforce and fulfill the right to freedom of religion and belief [13].

The state's obligation to protect and fulfill the right to freedom of religion and belief implies that the state does not have the authority to interfere with the affairs of religion and belief of every citizen. On the other hand, the state must provide protection for every citizen to carry out religious worship / belief without being restricted under any circumstances, even when the state is in an emergency. The state, government and DPR have a commitment to be bound 
by the International Covenant on Civil Rights. A state that imposes a certain religion on its people will endanger political stability. This is also explained by Spinoza, that the imposition of belief on the people will result in civil, political and religious rebellion [12].

Therefore, it is necessary to have synergy between the government as a policy maker and the community as the perpetrator. In making policies, the government must pay attention to the aspirations of the developing community, so that the policies made can be applied. The government must also be proactive in encouraging the realization of religious tolerance and facilitating people's desire to get closer to one religion to another or between one sect and another.

3.2. Weaknesses of the Joint Regulation of the Minister of Religion and the Minister of Home Affairs Number 9 and Number 8 of 2006 CHAPTER IV concerning the establishment of houses of worship in accommodating the establishment of houses of worship in an equitable manner

\section{Weaknesses of PBM Regarding Requirements for Establishing Houses of Worship Based on Legal Structure Perspective.}

Lawrence M. Friedman argues that the elements of the legal system consist of a legal structure, legal substance and legal culture. first is the legal structure [18]. In the perspective of the legal structure, it is said that:

"The structure of a system is its skeleton or framework; it is the permanent shape, the institutional body of the system, the though rigid none that keep the process flowing within bounds...The structure of a legal system consists of elements of this kind: the number and size of courts; their jurisdiction (that is, what kind of cases they hear, and how and why); and modes of appeal from one court to another. Structure also means how the legislature is organized, how many members... what a president can (legally) do or not do, what procedures the police department follows, and so on. Structure, in a way, is a kind of cross section of the legal system? A kind of still photograph, which freezes the action" [19].

Based on this definition, it can be briefly said that the legal structure is related to institutions or law enforcement including their performance (law enforcement). The substance of the law includes legal material, which among others is set forth in statutory regulations. legal structure concerning the institution (institution) that enforces the law, the authority of the institution and personnel (law enforcement apparatus). while legal culture concerns the behaviour (law) of society. These three elements influence the success of law enforcement in a society (state), which synergize with one another to achieve the goal of law enforcement itself, namely justice.

The legal structure concerns law enforcement institutions (institutions) in terms of PMB implementation in the construction of houses of worship by involving institutions in the central and regional governments. The application for a permit to build a house of worship is legally fundamental to PBM number 8 and 9 of 2006 which is stipulated by the central government. The institutional apparatus in the regions in fulfilling the requirements starts from the level of the village head / lurah, sub-district head, the ministry of religion, the forum for religious harmony based on the PBM. Meanwhile, for the consideration of determining the IMB of the regional government in this case, apart from being guided by the completeness of the required documents from the PMB, it also refers to Law number 28 of 2002 concerning buildings and buildings. In addition to this, the Medan city government also specifically refers to the Medan mayor regulation number 44 of 2018 concerning building permits levies [20]. 
Analysing the relevance of the Joint Ministerial Regulation, hereinafter referred to as PMB for the establishment of houses of worship, when linked to the legal system from a legal perspective, the legal structure can be seen from its weaknesses in terms of legal institutions governing houses of worship. So important is the house of worship as a visualization of the religious practice of a religious community in the country of Indonesia that has never been systematically regulated in integrated legislation, starting from: Laws, Government Regulations, Presidential Regulations, Ministerial Regulations, Regional Government Regulations. This shows the weaknesses that occur from the perspective of the legal structure, so it is natural that there are weaknesses in these regulations when used in the community.

\section{Weaknesses of PBM Regarding Requirements for Establishing Houses of Worship Based on the Perspective of Legal Substance}

The substance of the law (legal material) is illustrated by Lawrence M. Friedman: "The substance is composed of substantive rules and rules about how institutions should behave. By this is meant the actual rules, norm, and behavioural patterns of people inside the system ...the stress here is on living law, not just rules in law books "[18]. Substance means the actual rules, norms and patterns of behaviour of people in the system. The emphasis is on living law, not just laws in book. The substance or content of the law as a reference in law enforcement has an important role as a guideline or guideline for law enforcers in exercising authority. This means that weaknesses in the content of the law will result in ineffective implementation of the law so that the objectives to be achieved are not fulfilled.

The context of the weaknesses of the Joint Ministerial Regulation regarding the establishment of houses of worship in the perspective of legal substance is in Chapter IV Article 14 concerning the requirements for the construction of places of worship which reads:

1. Construction of houses of worship must meet the administrative and technical requirements of the building.

2. In addition to meeting the requirements as referred to in paragraph (1), the establishment of a house of worship must meet special requirements including:

a. a list of names and Identity Cards of users of houses of worship at least 90 (ninety) people legalized by local officials in accordance with the level of boundaries as referred to in Article 13 paragraph (3);

b. support from the local community of at least 60 (sixty) people who are endorsed by the lurah / village head;

c. written recommendation from the head of the regency / municipality religious department office; and

d. written recommendation from district / city FKUB.

3. If the requirements as referred to in paragraph (2) letter a are met while the requirements in letter $\mathrm{b}$ have not been fulfilled, the regional government is obliged to facilitate the availability of locations for the construction of houses of worship [8].

Analysing the legal substance of PBM in its implementation in Buddhist society, especially in the city of Medan, based on the author's interview technique with Buddhist figures and followers, it can be explained that the requirements for the construction of a house of worship are hard to fulfil. The difficulty in fulfilling the requirements for the establishment of houses of worship based on the PBM is that the number of users and supporters of houses of worship that must be fulfilled is too large. Buddhists in areas with large communities will have no difficulty in fulfilling the requirements for the establishment of houses of worship, but it would be very different in a region with a limited Buddhist community that would be very difficult to implement in realizing the establishment of houses of worship. 
Chapter IV Article 14 PBM number 9 and number 8 of 2006 has locked in difficulties in fulfilling the requirements for the construction of houses of worship. The weakness of article 14 is that it requires 60 (sixty) potential users of the synagogue to build a house of worship. Furthermore, 90 (ninety) supporters are also required for the establishment of a house of worship as evidenced by an Identity Card (KTP) and legalized by the Village Head, Camat, Ministry of Religion and FKUB. After the complete file is submitted to the local PTSP to be registered, it is necessary to grant a Building Construction Permit (IMB) for the building for the function of a place of worship in accordance with the provisions of the respective regional regulations.

The government, in this case the Minister of Religion and the Minister of Home Affairs, in determining the requirements for the establishment of houses of worship contained in Chapter IV Article 14 does not consider the real condition, that in each region there is a diversity of the number of different religions. Thus, it will be difficult to be fulfilled by a community that is small in number but in reality, requires the existence of a house of worship for religious activities.

Consideration of rights and freedom in embodying the practice of worship, also does not pay attention to the values of dignified justice in stipulating Chapter IV article 14 PBM number 9 and 8 concerning the construction of houses of worship. This is very contradictory to Article 29 of the 1945 Constitution concerning Religious Freedom. (1) The state is based on the one and only Godhead. (2) The State guarantees the freedom of every resident to embrace his own religion and to worship according to his religion and belief. So that objections will be felt by the community with a minimal quantity.

The special thing that the government considers in the PBM is only to put forward the aim of creating harmony between religious communities only, but does not pay attention to the actual implementation in its application in the field. The weakness of this regulation actually triggers conflict, if it cannot be properly resolved, the problem is that the requirements for the construction of houses of worship are not fulfilled.

Besides not considering the juridical aspects of higher regulations, the stipulation of regulations with the minister also does not pay attention to actual conditions on the ground. The difficulty in fulfilling the requirements for the establishment of houses of worship in the form of user and supporting documents is not as easy as what is in the regulatory text. This limitation actually triggers problems due to the formulation of requirements that does not pay attention to reality.

The difficulty in fulfilling the requirements in terms of the number of users and supporters for establishing a house of worship is felt especially hard for a community with a small number in an area. This, in fact, is not the fault of a community that cannot meet the requirements referred to. However, it is caused by a weakness in regulations that have been determined but do not consider community, territorial and justice aspects.

\section{Weaknesses of PBM Regarding Requirements for the Construction of Houses of Worship Based on a Legal Culture Perspective}

Lawrence M. Friedman describes legal culture: "The legal culture, system their beliefs, values, ideas and expectation. Legal culture refers, then, to those ports of general culture customs, opinions ways of doing and thinking that bend social forces toward from the law and in particular ways....in other word, is the eliminate of social thought and social force which determines how law is used, avoided, or abused" [19].

Legal culture (legal culture) which defines the belief system, values, ideas and conjectures. Legal culture refers to general cultural habits, ways of expressing opinions and thinking towards 
the social forces of law and in certain ways, in other words, whether the climate of social thought and social forces determines how laws are used, avoided, or abused.

Legal culture concerns the legal culture which is the attitude of humans (including the legal culture of law enforcers) towards the law and the legal system. No matter how good the legal structure is to carry out the stipulated legal rules and no matter how good the quality of the legal substance made without the support of legal culture by people involved in the system and society, law enforcement will not run effectively [18].

The relationship between PMB, seen from the aspect of legal culture, lies in the culture of implementing PBM which is still widely carried out outside the provisions. Several casuistic examples of legal uncertainty over the construction of houses of worship that are rejected or do not receive approval from the local community. The weakness of implementing this legal culture is detrimental to all parties, on the part of the petitioner it is certain that they are disadvantaged because they cannot apply religious needs together with the community. Likewise, stakeholders are also faced with problems that are difficult to provide the best solution due to limitations that arise from regulations.

Patterns of Harmonized Relationships Religious people basically want peace and harmony together, because such an atmosphere makes social life between religious people able to carry out their respective lives without interfering with the religions and beliefs of religious communities. The religious beliefs and obedience that a person adheres to are very influential in creating harmony between religious communities because there is no single religion that teaches contradiction, let alone disputes that lead to disharmony, in fact all religions advocate living in harmony and harmony. Another factor that helps create religious harmony is the customary ties adhered to by the people of North Sumatra, especially the city of Medan. Which in this custom teaches how important it is to live side by side with one ethnic group and another and one religion with another in society [21].

North Sumatra, especially Medan City. In one family, we often encounter marriages with different cultural backgrounds and even different religions in other words, there are several mixtures of different ethnic groups and religious marriages in one family. This can also trigger the implementation of harmony in society. Involvement of relatives who may have different religions in the implementation of a traditional party in Medan, which invited many relatives to join the "Dalihan Na Tolu" bond (Mora Kahanggi and Anak Boru). This bond conditions each person to work as a team for the smoothness and success of the traditional party. This process when working together familiarizes a sense of kinship so that harmony and involvement with each other are strong.

Even though the people of North Sumatra, especially the city of Medan, are very heterogeneous, the above realities make every problem related to social life or religious life not too difficult to solve. The problems that occur are resolved by deliberation, even though they are carried out with different siblings in terms of beliefs and customs but this is not a barrier, precisely through this family factor, mutual respect, mutual respect and upholding togetherness will be created. become bond with each other. The existence of this relatively harmonious condition of Medan City does not mean that there are no misunderstandings or conflicts in their interactions. There are still conflicts or disharmony, but with the level of awareness and tolerance the people of Medan are highly respected for, the conflict and misunderstanding have no further impact. 
3.3. Solution to the Joint Regulation of the Minister of Religion and the Minister of Home Affairs Number 9 of 2006 and Number 8 of 2006 CHAPTER IV Article 14 Concerning the Construction of Houses of Worship Cause Difficulties in the Construction of Buddhist Houses of Worship in Medan City

\section{Expectations of Changes in Rules in the Requirements for Establishing Houses of Worship}

The state guarantees freedom of religion with several rules that have permanent legal force and must be respected, consisting of:

1. Article 28E (1) and Article 29 (2) of the 1945 Constitution;

2. Law No. 39 of 1999 concerning Human Rights Article 22 paragraph (1);

3. Law No. 12 of 2015 concerning Ratification of the International Covenant on Civil and

Political Rights Article 18 paragraph (1): Based on the existence of freedom of religion for the people of Indonesia, then of course the house of worship is the most important thing for a religion, but in the legal system in Indonesia, every establishment of a house of worship must obtain permission to establish a house of worship. Furthermore, juridically, the implementation of worship is one of the government instruments which functions to fulfil human rights. One of the main problems in a democratic country is equal position among citizens, where the state and the law must protect their citizens equally, without one being born and the other being a child. This is known as the principle of equal protection before the law [22].

Article 27 paragraph (1) of the 1945 Constitution expressly determines that every citizen shall have an equal position in law. Government and obliged to uphold the law and Government without exception. Therefore, the principle of equal protection before the law (equality for all people to obtain equal rights before the law) has actually inspired the Indonesian nation for a long time because it has long been a mandate of the Constitution. The equal position in law and government in a democratic country shows its format in one of the following ways:

"The equal position between the majority group and the minority group is in a certain stigma relationship. For example, the need for protection of race or ethnicity, religion, colour, sect in a certain religion, which is included in the minority group. In this case, the concept of a democratic state must apply the principle known as majority rule minority rights [22].

The difficulty of implementing regulations in granting permits for the construction and use of buildings, especially by religious minorities, often does not refer to their views because this is done to ensure that the physical growth of the city of Medan in order to support economic growth as a whole does not cause damage to the physical arrangement of the city of Medan. For every building construction activity in the city of Medan, the community must first take care of and obtain a Building Construction Permit (IMB) in accordance with the applicable provisions Building Construction Permit (IMB) is intended so that construction can run smoothly and unwanted things do not occur. at a later time.

Meanwhile, at the time of using the building, it must first obtain a Building Use Permit (IPB). The permits granted to construct a building are fulfilled in accordance with the administrative and technical requirements of the building. As for the legal basis for building construction according to the Hierarchy of Legislation Law no. 12 of 2011 concerning According to Yunus Wahid, 2014 Formulation of Legislation, Article 7 paragraph 1 is: (a) Pancasila, (b) the 1945 Constitution of the Republic of Indonesia, (c) Law of the Republic of Indonesia No. 28 of 2002 concerning Buildings, (d) Law of the Republic of Indonesia No. 26 of 2007 concerning Spatial Planning, (e) Government Regulation No. 36 of 2005 concerning Implementers of Law No. 28 of 2002 concerning Buildings, (f) Regulation of the Minister of 
Home Affairs of the Republic of Indonesia No. 32 of 2010 concerning the Granting of Building Construction Permits[23].

Building construction permit issuance services, in fact, can be carried out with a one-stop service pattern, namely the pattern of licensing services that are carried out in an integrated manner at one place / location by several Medan city government agencies involved in the process of issuing building permits, for example the Spatial Planning Service and Building Management regarding the publication of information on city plans, planning advice; Regional Office of BPN regarding land certificates; P2B Office regarding the IMB; Architecture Team, Advisory Team, and so on. Likewise, the counters must be put together in one location so as to provide convenience to applicants for building permits [22].

According to Riduan, the license is a juridical instrument used by the government to influence citizens to follow the recommended method in order to achieve concrete goals. As an instrument, a permit functions as the spearhead of a legal instrument as a director, engineer, and designer for a just and prosperous society. This means, through permission, it can be seen how the image of a just and prosperous society can be realized. This means that the requirements contained in the license are controls in the functioning of the license itself. One of the enforcements of state administrative law is the permit to build houses of worship which is carried out.

\section{Solutions in Overcoming Difficulties in Establishing Buddhist Houses of Worship in Medan City}

The problem of the difficulty of establishing a Buddhist synagogue in Medan city based on the results of interviews with Buddhist figures and followers can be formulated as follows:

1. Not able to meet the requirements of 60 people of worship house users, because the Buddhist community is small and insufficient.

2. Not being able to meet the requirements of supporting the establishment of Buddhist synagogues as many as 90 people, because they are in the midst of other religious communities.

Seeing the fact of the difficulties in the construction of houses of worship mentioned above, there is an expectation that the PBM regulations on houses of worship can be changed to become lighter. So that Buddhists can establish a synagogue in the city of Medan without difficulty. However, this regulatory change is still an expectation and discourse. Through the results of interviews with Buddhist leaders and followers in the city of Medan, data was obtained that the solution for the construction of Buddhist houses of worship in the city of Medan in order to meet the PMB requirements can be done with the following efforts:

Looking for land for the construction of houses of worship in a community area with a large number of Buddhists.

1. Looking for land far from the village so that it is easy to get support.

2. Taking a humane approach to the surrounding environment to get support in the construction of houses of worship.

The first step is to find land for the construction of houses of worship in a community area with a large number of Buddhists. This can be done if the Buddhist community that will build a synagogue has sufficient funds. Land close to many Buddhist communities is usually in residential areas of Chinese residents where the average price of land is high. Therefore, the first alternative can only be made by certain Buddhist circles.

The second alternative is land that is far from the village so that it is easy to get support. This option is usually easier to realize the establishment of Buddhist synagogues. However, there was a drawback in that the synagogue was far from where the Buddhists lived. Thus, it 
will allow the synagogue to be ineffective and inefficient to be used and functioned optimally [24].

The third option is to choose a humane approach to the surrounding environment to get support in the construction of houses of worship. This step is quite effective, namely with the land owned by making efforts to establish good relations with the surrounding environment to obtain approval for support in the construction of houses of worship. If successful, the house of worship will be realized with good support from the local population [25].

According to Mr. Rames Kumar, he explained that through both the regulatory and psychological approaches carried out by Buddhists, they have been able to map out the problems that will be discussed at higher levels, especially coordination at the provincial level. Even the Ministry of Religion at the regional level will facilitate requests to the Ministry of Religion in the province. Even though they don't get support from surrounding groups, at least the government has a very important role to play in preparing where they should be able to pray.

Based on Mr. Rames Kumar's opinion, it can be concluded that the average Buddhist in Medan is able to socialize and communicate with local religious communities. This has the potential for Buddhists to maintain harmony between religious communities and allows them to gain support in the establishment of houses of worship as a form of religious tolerance.

\section{Conclusion}

a. The legal arrangement for the establishment of houses of worship in Indonesia is determined by the government in the form of joint regulations of the Minister Number 9 and 8 of 2006 Chapter IV Article 14 concerning the construction of houses of worship. It is difficult for a community to fulfil PBM with a small number of people, so that it is contradicting the 1945 Constitution and Article 4 jo. Article 22 of Law Number 39 Year 1999 concerning Human Rights which guarantees freedom of religion is the right of every Indonesian citizen to be able to regulate his or her respective religion and belief.

b. The weakness of the Joint Regulation of the Minister of Religion and the Minister of Home Affairs Number 9 and 8 of 2006 Chapter IV concerning the Establishment of Houses of Worship is that it is contained in Article 14 which requires that the construction of houses of worship must be required for 60 (sixty) potential users of houses of worship and 90 (ninety) ) Support for the establishment of houses of worship as evidenced by a National Identity Card (KTP) and legalized by the Village Head, Camat, Ministry of Religion, and FKUB. After the complete files are submitted to the local PTSP to register, they must be granted a Building Construction Permit (IMB) for the building functions for places of worship in accordance with the provisions of the respective regional regulations.

c. The solution in overcoming difficulties in the construction of Buddhist houses of worship in Medan is to seek alternative steps that meet the requirements in the PBM, such as providing strategic and supportive land as well as humanist communication approaches to gain support in the establishment of worship.

\section{References}

[1] Desi Purnamasari, "Problem Umat Agama Minoritas: Susah Mendirikan Rumah Ibadah," tirto.id Sosial Budaya, 2019. . 
[2] A. Farida, "Pendirian Rumah Ibadat Pasca PBM Nomor 9 Dan 8 Tahun 2006 dan Kerukunan Umat Beragama (Kasus Pendirian Gereja di Kota Bandung, Jawa Barat)," Harmoni, vol. 16, no. 2, pp. 374 392, 2018, doi: 10.32488/harmoni.v16i2.5.

[3] Y. Afiyanti, "Penggunaan Literatur Dalam Penelitian Kualitatif," J. Keperawatan Indones., vol. 9, no. 1, pp. 2003-2006, 2014, doi: 10.7454/jki.v9i1.157.

[4] K. H. Dewantara, "Deskripsi Kualitatif Sebagai Satu Metode Dalam Penelitian Pertunjukan," Harmon. J. Arts Res. Educ., vol. 11, no. 2, pp. 173-179, 2011, doi: 10.15294/harmonia.v11i2.2210.

[5] D. sudrajat and I. Moha, "Ragam Penelitian Kualitatif," Equilibrium, vol. 5, pp. 1-8, 2019, doi: 10.31227/osf.io/jaxbf.

[6] Wayne Parsons, Pengantar Teori dan Praktik Analisis Kebijakan. Jakarta: Kencana, 2008.

[7] T. Penyusun, "Keputusan Bersamamenteri Agama Dan Menteri Dalam Negeri No. 01/BER/mdnmag/1969 Tentang Pelaksanaan Tugas Aparatur Pemerintahan Dalam Menjamin Ketertiban Dan Kelancaran Pelaksanaan Pengembangan Dan Ibadat Agama Oleh Pemeluk-Pemeluknya.”.

[8] T. Penyusun, "Peraturan Bersama Menteri Agama dan Menteri Dalam Negeri Nomor 9 dan Nomor 8 Tahun 2007 Tentang Pedoman Pelaksanaan Tugas Kepala Daerah/Wakil Kepala Daerah Dalam Pemeliharaan Kerukunan Umat Beragama, Pemberdayaan Forum Kerukunan Umat Beragama, dan Pendiri," vol. 53, no. 9. pp. 1689-1699.

[9] B. Asrianto, "Peraturan Bersama Menteri Agama Dan Menteri Dalam Negeri Nomor 08 Dan 09 Tahun 2006 Tentang Pendirian Rumah Ibadat (Kajian Dalam Perspektif Hak Asasi Manusia )," no. Pasal 29, pp. 1-12, 2006.

[10] Azhari, Negara Hukum Indonesia. Jakarta: UI PRESS, 1995.

[11] E. S. Muhardi Hasan, "Hak Sipil dan Politik," Demokrasi, vol. 4, no. 1, p. 49, 2001.

[12] D. Andi, "Demokrasi Di Indonesia: Antara Pembatasan dan Kebebasan Beragama," Analisa, vol. XVII, no. 01, pp. 9-18, 2019, doi: 10.31219/osf.io/w5ejk.

[13] J. kameo Teguh Prasetyo, "Peradilan Hak Asasi Manusia: Suatu Perspektif Menurut Jurisprudence Keadilan Bermartabat," J. Ilmu Huk., vol. 15, no. 2, pp. 143-154, 2020.

[14] P. Astomo, "Prinsip-Prinsip Negara Hukum Indonesia dalam UUD Negara Republik Indonesia Tahun 1945," J. Huk. Unsulbar, vol. 1, no. 1, pp. 1-12, 2018, doi: 10.31605/j-law.v1i1.47.

[15] Hermanto Bambang, "Analisis Yuridis Normatif Terhadap Peraturan Bersama Menteri Agama dan Menteri Dalam Negeri Nomor 9 Tahun 2006 Dan Nomor 8 Tahun 2006," 2010, doi: http://dx.doi.org/10.24014/trs.v2i1.425.

[16] M. Zainuddin, "Perdebatan di Seputar Pluralisme Agama," vol. 8, no. 1, pp. 1689-1699, 2009.

[17] Destriana Saraswati, "Pluralisme Agama Menurut Karen Armstrong," J. Filsafat, vol. 23, no. 3, pp. 186-198, 2013, doi: 10.22146/jf.32964.

[18] L. F. M, The Legal System, A Social Science Perspective. New York: Russel Sage Foundation, 1974.

[19] L. Friedman, "Penerapan Sistem Hukum Menurut Lawrence W Friedman Terhadap Efektivitas Perlindungan Desain Tata Letak Sirkuit Terpadu Berdasarkan Undang-Undang Nomor 32 Tahun 2000," Al Amwal (Hukum Ekon. Syariah), vol. 2, no. 1, pp. 78-94, 2019, [Online]. Available: http://literaturbook.blogspot.co.id/2014/12/pengertian-efektivitas-dan-landasan.

[20] T. Penyusun, "Peraturan Wali Kota Medan Nomor 44 Tahun 2018 Tentang Retribusi Izin Mendirikan Bangunan.".

[21] M. Aswin, "Model Pola Hubungan Harmoniasi Antar Umat Beragama Di Kota Medan,” J. Anal. Islam., vol. 2, no. 2, pp. 292-303, 2013, [Online]. Available: http://jurnal.uinsu.ac.id/index.php/analytica/article/view/408.

[22] Abdul Aziz Hakim, Negara Hukum dan Demokrasi di Indonesia. Yogyakarta: Balai Pustaka, 2011.

[23] M. Firdaus et al., "Legalitas Pendirian Rumah Ibadat Berdasarkan Peraturan Bersama Menteri Agama Dan Menteri Dalam Negeri Nomor 9 Tahun 2006," Usu Law J., vol. 19, no. 1, pp. 165-182, 2016, doi: 10.31849/respublica.v16i1.1434.

[24] Sendy Febriyanto, "Hasil wawancara penulis dengan tokoh agama Buddha," Medan, 2020.

[25] Rames Kumar, "Hasil wawancara penulis dengan Penyenggara Bimas Kota Medan," Medan, 2020. 